\title{
Bariatrik Cerrahinin Beslenme Okuryazarlığı Üzerine Etkisi: Bir Vaka-Kontrol Çalışması
}

\section{The Effect of Bariatric Surgery on Nutrition Literacy: A Case-Control Study}

\author{
${ }^{1}$ Pınar YILMAZ, ${ }^{1}$ Meryem YILMAZ \\ ${ }^{1}$ Sivas Cumhuriyet Üniversitesi, Sağlık Bilimleri Fakültesi, Hemşirelik Bölümü, Cerrahi Hastalıkları Hemşireliği AD, Sivas, Türkiye
}

Pinar Yilmaz: https://orcid.org/0000-0002-4696-8776

Meryem Y1lmaz: https://orcid.org/0000-0001-7686-3572

\section{ÖZ}

Amaç: $\mathrm{Bu}$ çalışma bariatrik cerrahinin(BC) beslenme okuryazarlığı üzerinde bir etkisi olup olmadığını araştırmak amaciyla planlandi.

Materyal ve Metot: Araştırma deneysel tipte bir vaka kontrol çalışmasıdır. Çalışma 30'ar kişilik deney ve kontrol gruplarından oluşmaktadır. Veriler araştırmacılar tarafindan geliştirilen anket formu ve "Beslenme Okuryazarl1ğ1 Ölçeği” kullanılarak elde edildi.

Bulgular: Deney grubunun yaş ortalaması $36 \pm 7,79$ ve $\% 53,3$ 'ü kadındı. Kontrol grubunun yaş ortalaması $34,5 \pm 8,35$ idi, \% 56,7'si kadınd1. BC öncesi toplam beslenme okuryazarlığı puanı $20.10 \pm 5.68$ ve toplam ameliyat sonras1 beslenme okuryazarlığı puanı $29.57 \pm 3.07$ idi. Kontrol grubunun toplam beslenme okuryazarlığı puan $23,73 \pm 6,18$ idi. BS sonras1, deney grubunun beslenme okuryazarlığ istatistiksel olarak anlamlı bir fark bulundu. Beslenme okuryazarlığı ile tanımlayıcı özellikler (eğitim düzeyi ve beslenme konusundaki bilgi düzeyi hariç) arasında anlamlı bir ilişki yoktu. Bununla birlikte, BC'den önce beslenme düzeyi ile beslenme okuryazarlığı arasında anlamlı negatif korelasyon vardı. BC'den sonra, sadece eğitim düzeyi ile beslenme okuryazarlığ arasında istatistiksel olarak anlamlı bir ilişki bulundu.

Sonuç: Bariatrik cerrahinin beslenme okuryazarlığ üzerinde olumlu etkisinin olduğu sonucuna varıldı. Bariatrik cerrahi geçiren bireylerin beslenme konusunda daha araştırmacı olduğu söylenebilir.

Anahtar Kelimeler: Bariatrik cerrahi, beslenme okuryazarlığı, hemşirelik

\begin{abstract}
Objective: This study was planned to investigate whether bariatric surgery (BS) has an impact on nutritional literacy.

Materials and Methods: The research is an experimental type case-control study. The study consists of thirty-person experimental and control groups. The data were obtained by using the questionnaire form developed by the researchers and the "Nutrition Literacy Scale".

Results: The average age of the case group was $36 \pm 7.79$ and $53.3 \%$ were women. The mean age of the control group was $34.5 \pm 8.35,56.7 \%$ were women. The total nutrition literacy score before BS was $20.10 \pm 5.68$ and the total postoperative nutrition literacy score was $29.57 \pm 3.07$. The total nutrition literacy score of the control group was $23.73 \pm 6.18$. After BS, a statistically significant difference was found between the nutritional literacy total score of the experimental group and the control group. There was no significant relationship between nutrition literacy and caracteristics (except education level and level of knowledge about nutrition). However, there was a significant negative correlation between nutritional level of nutrition and nutrition literacy before BS. After BS, only a statistically significant relationship was found between education level and nutrition literacy.

Conclusions: It was concluded that bariatric surgery had a positive effect on nutritional literacy. It can be said that individuals who have undergone bariatric surgery are more researchers about nutrition.
\end{abstract}

Keywords: Bariatric surgery, nursing, nutrition literacy
Gönderi Tarihi/ Received: 17/02/2020

Sorumlu Yazar / Corresponding Author:

Pinar Yilmaz

Sivas Cumhuriyet Üniversitesi, Sağlık Bilimleri Fakültesi, Hemşire-

lik Bölümü, Cerrahi Hastalıkları Hemşireliği AD, Sivas, Türkiye

Tel: 05309468919

E-mail: yilmazpinar20@gmail.com
Gönderi Tarihi/ Received: 17/02/2020

Online Yayın Tarihi/ Published: 30/09/2020

Atıf / Cited: Y1lmaz P ve Y1lmaz M. The effect of bariatric surgery on nutrition literacy: a case-control study. Online Türk Sağllk Bilimleri Dergisi 2020;5(3):424-433. doi: 10.26453/otjhs.690018 


\section{INTRODUCTION}

Recently, the term of "literacy" has been used frequently in academic literature. Nutrition literacy beyond basic literacy is defined as the ability to read and understand complex food information. ${ }^{1,2}$ Nutrition literacy is an up-to-date concept proposed to determine how much individuals can receive, process and understand the basic nutritional information and services they need to make appropriate nutritional decisions ${ }^{3,4}$ Nutritional literacy has an impact on obesity as well as in many chronic diseases. ${ }^{5}$ Obesity, which is a worldwide epidemic can be treated with diet, exercise, behavior change, pharmacological and surgical methods (bariatric surgeryBS). ${ }^{6} \mathrm{BS}$ is associated with significant and strong weight loss, improvement or decrease in comorbidities $^{7,8}$ and mortalities ${ }^{9,10}$ has been recognized as the most effective long-term treatment for morbid obese. ${ }^{11}$ However, BS is not without risk. Bariatric procedures can cause changes in the amount of nutrients and absorption quality as they cause changes in gastrointestinal anatomy and physiology. ${ }^{12}$ The long -term and successful outcome of BS depends on the lifelong nutrition and lifestyle changes of the patient. ${ }^{13}$ In this case, the question comes to mind : "What is the level of nutritional literacy of bariatric patients?" To be nutrition literate; requires understanding of nutrients and food groups, number literacy to read food labels, and measurement skills to pay attention to portion control. ${ }^{14}$ After BS, becoming a nutritional literate is a necessity. Because in bariatri patients, changes in calorie intake, changes in circadian dynamics, portion size, eating frequency, eating interval, and satiety ratio at specific stages of surgery are particularly important after surgery. ${ }^{15}$ In some studies, it was reported that less calorie, healthier foods are preferred after BS instead of high fat and sweet foods. ${ }^{16-19}$ This shows that BS not only increases saturation but also affects food preferences. In some studies, ${ }^{20-22}$ it was determined that the change of diet style was not consistent. Considering these differences between bariatric patients, it can be said that it is more important to be a nutritional literate after BS. In the literature, no study was found to determine the relationship between BS and nutrition literacy. Based on this information, this study was planned to investigate whether BS has an impact on nutritional literacy.

\section{MATERIALS AND METHODS}

The research is an experimental type case-control study. The study was conducted between July 1, 2017 and December 31, 2017, in Sivas Cumhuriyet University Hospital General Surgery Clinic and Polyclinic. Before data collection, approval from the ethics committees of the Sivas Cumhuriyet University on 15.06 .2017 where the study was conducted (Decision Number: 2017-06/02) and written permission from the institutional authority of the general surgery department were obtained. And this study performed with the 1964 Helsinki declaration and its later amendments or comparable ethical standards. The case group consisted of 30 patients who had not undergone BS because of morbid obesity. The control group consisted of 30 subjects with normal body mass index, similar to the case group in terms of age, sex, marital status, educational level and presence of chronic disease. The total number of people applying for BS was 33 between these dates. However, since individuals should be followed for 3 months, three patients from outside the city were excluded from the study. The data were obtained by using the questionnaire form developed by the researchers and the "Nutrition Literacy Scale". The purpose of the study was explained to all individuals and their written consent was obtained.

Case group: The case group consisted of individuals who applied to the policlinic due to morbid obesity and were decided to have surgery.

Inclusion criteria for case group;

-People who decided to undergo BS due to morbid obesity,

-Individuals over the age of 18 ,

-Individuals with literacy,

- Individuals without communication problems.

Individuals who agree to participate in the study

The preoperative forms were applied in the policlinic room and telephone numbers of the individuals were obtained. After BS, individuals were phoned to each of them in the third month and the interview was planned. In the third month, the forms were reapplied in the policlinic room. The forms were given to the individuals and they were asked to fill out the forms within approximately 20-30 minutes.

Control Group: The forms were administered to healthy subjects who had normal BMI and did not undergo BS.

Inclusion criteria for control group;

-Individuals with normal BMI and BS

-Individuals over the age of 18 , 
-Individuals with literacy,

-Individuals without communication problems. individuals who agree to participate in the study These individuals were selected from hospital attendants. The forms were given to the individuals and they were asked to fill out the forms within approximately 20-30 minutes.

In order to prevent access from outside, the researcher waited with individuals until the form filled.

\section{Documents:}

Questionnaire Form: It was developed by the researchers. In this form; age, sex, marital status, educational status, occupation, presence of chronic disease, weight, height and body mass index, how to evaluate your level of knowledge about nutrition and how to get this information.

Nutrition Literacy Scale: It was developed by Cesur et al. in 2015. This scale is applicable to individuals aged between 18-64 years and at least primary school graduates. The scale consists of five parts. There are questions about general nutritional knowledge in the first part (10 questions), comprehension and interpretation of reading in the second part (6 questions), food groups in the third part (10 questions), portion amounts in the fourth part (3 questions), the ability to read the food label and simple calculation in the fifth part (6 questions). Each question answered correctly was evaluated as one point and incorrectly answered and left-handed questions were evaluated as zero points. The total score of the scale is 35 . Nutritional literacy average scores according to the sections of the scale are given in Figure 1. Nutritional literacy level between 0 11 points out of total score is considered to be insufficient. Nutritional literacy level between 12-23 points out of the total score is considered as borderline. Nutritional literacy level between $24-35$ points out of total score is considered sufficient. ${ }^{23}$

Statistical Analysis: Statistical analyses were performed using IBM Statistical Package for the Social Sciences (SPSS, version 22.0). Descriptive statistics (e.g., mean, standard deviation [SD], and frequency distributions were generated for all variables. Demographic differences between case and control groups were tested using independent t-tests or Mann-Whitney U tests, as appropriate, for continuous variables and the Kruskal-Wallis $\mathrm{H}$ test for discontinuous variables. Student's t-tests were conducted to compare Nutrition Literacy Scale and the following time. Finally, we carried out simple linear regression analyses between nutritional literacy scores and individual characteristics. The level of signi- ficance for all analyses was set at $\mathrm{p}<0.05$.

\section{RESULTS}

Table 1 shows the descriptive characteristics of individuals. As seen in the table, the average age of the case group was $36( \pm 7.79), 53.3 \%$ were women, $66.7 \%$ were married, $46.7 \%$ were high school graduates, $70 \%$ had no chronic disease, $16.7 \%$ of those with chronic disease had diabetes mellitus. Half of the case group participated in the study had sleeve gastrectomy and the remaining half had Roux N-Y gastric bypass surgery. The mean age of the control group was $34.5( \pm 8.35), 56.7 \%$ were women, $60 \%$ were married, $70 \%$ were high school graduates, $73.3 \%$ had no chronic disease, $23.3 \%$ of those with chronic disease had diabetes mellitus. Body mass index of the case group before BS was $44.13 \pm 5.73$, and body mass index was $33.73 \pm 5.56$ at 3 months after BS. The body mass index of the control group was within normal limits and the mean was $21.40 \pm 1.75$. While $53.3 \%$ of the patients stated that they had sufficient nutritional knowledge before BS, $70 \%$ of patients had adequate nutritional knowledge after surgery. It was determined that the individuals in the case group followed the information about nutrition before the BS from the media the rate of $46.7 \%$. After BS, it was determined that most of the information about nutrition $(60 \%)$ was learned from the internet. On the other hand, $76.7 \%$ of the control group stated that they had sufficient nutritional knowledge and $80 \%$ of them stated that they learned from the internet about the knowledgeable about nutrition.

Table 2 shows the mean nutritional literacy scores between the case and control groups. The total nutritional literacy score before BS was 20.10 \pm 5.68 and the total postoperative nutritional literacy score was $29.57 \pm 3.07$. The total nutrition literacy score of the control group was $23.73 \pm 6.18$. As seen in the table, the case group was prominent in the dietary literacy score after BS with a statistically significant difference compared to the control group.

In Table 3 , simple linear regression analysis showing the relationship between the characteristics and nutritional literacy is given of bariatri patients. When the table is examined; there was no significant relationship between nutritional literacy and age, sex, marital status, educational status, presence of chronic disease, body mass index, type of surgery and nutritional knowledge. However, there was a significant negative correlation between nutritional level of nutrition and nutritional literacy before the 
operation. After BS, only a statistically significant relationship was found between education level and nutrition literacy.

\section{DISCUSSION AND CONCLUSION}

After BS, a process begins in which individuals must adapt to their new life. In this process, cooperation of surgeon, nurse and nutritionist is very important. As a matter of fact, this team determines the rules that patients should follow after surgery. One of the most important rules after BS is to maintain the diet. The prior knowledge of the person has an important role in maintaining this order. Therefore, we designed this study as a case-control type to determine the effect of BS on nutritional literacy.

One of the variables that affect nutritional literacy is to have various skills for individuals to understand and critically evaluate the complex information about nutrition and to transform it into healthy nutrition practices. ${ }^{24}$ Therefore, the effect of education level on nutritional literacy is clearly understandable. Studies ${ }^{25,26}$ have shown that there is a positive relationship between higher education level and nutrition literacy. In this study, according to the literature, a statistically significant increase in the nutritional literacy rate of BS patients was found. This situation can be interpreted as the level of education is important in nutrition research, obtaining information and interpreting information in individuals who have undergone BS.

Nutrition literacy has a dynamic structure. ${ }^{27}$ It is emphasized that the desire, skills, attitudes, behaviors and abilities are also needed to provide nutritional literacy in addition to knowledge. As a matter of fact, in previous studies, it was stated that nutritional information alone is not sufficient for healthy nutrition, ${ }^{27,28}$ nutrient selection and applications and there is a need for motivation. ${ }^{29}$ In this study, nutritional literacy of individuals after BS was statistically improved. In this case, BS can be said to be a source of motivation in patients because of both adaptation to new life and desire for weight loss.

In the postbariatric period, individuals are required to follow multi-stage diets and nutritional contents may vary depending on the type of surgery. ${ }^{30}$ Therefore, bariatri patients have to adapt to nutritional changes in the postoperative period. In this study, it was concluded that BS had a positive effect on nutritional literacy score. This can be interpreted as the individuals who participated in the study were successful in adapting to BS in the postoperative period and increased their literacy level by conducting research on nutrition.

As a result, after BS, individuals' nutritional literacy levels increased.Based on the results of the study, it is recommended that nutritional literacy levels of bariatri patients should be examined with further research. In addition, it is important to repeat this study with more bariatri patients in more intensive BS centers and to conduct experimental studies with longer follow-up in order to raise awareness of nutritional literacy for patients.

One of the limitations of the study is the small number of patients who applied to the institution for BS between the dates of the study. In addition, it was observed that patient follow-up was insufficient in terms of nutrition after BS, therefore it was determined that individuals needed nutritional education to be given correctly, which is another limitation of the study.

Ethics Committee Approval: Before datas collection, approval from the ethics committees of the Sivas Cumhuriyet University on 15.06.2017 where the study was conducted (Decision Number: 201706/02)and written permission from the institutional authority of the general surgery department were obtained. This study performed with the $1964 \mathrm{Hel}-$ sinki declaration and its later amendments or comparable ethical standards.

Conflict of Interest: No conflict of interest was declared by the authors.

Author Contributions: Concept-M.Y., P.Y.; Design -M.Y., P.Y.; Supervision-M.Y., P.Y.; ResourcesM.Y., P.Y.; Materials-M.Y., P.Y.; Data Collection and/or Processing-P.Y.; Analysis and/or Interpretation-P.Y.; Literature Search-M.Y., P.Y.; Writing Manuscript-P.Y.; Critical Review-M.Y.

Peer-review: Externally peer-reviewed.

\section{REFERENCES}

1. Ndahura NB. Nutrition literacy status of adolescent students in Kampala district, Uganda, Oslo and Akershus University College of Applied Sciences, PhD thesis. Lillestrøm, Norway.2012.

2. Laberge M. Nutritionhttps://www.diet.com/g/ nutrition-literacy?get=nutrition-literacy.2011;12. Accessed january 12,2019

3. Collins SA, Currie LM, Bakken S, Vawdrey DK, Stone PW. Health literacy screening instruments for eHealth applications: A systematic review. Journal of Biomedical Informatics. 2012;45 (3):598-607. doi: 10.1016/j.jbi.2012.04.001 
4. Silk KJ, Sherry J, Winn B, Keesecker N, Horodynski MA, Sayir A. Increasing nutrition literacy: Testing the effectiveness of print, web site and game modalities. Journal of Nutrition Education Behavior. 2008;40(1):3-10. doi: 10.1016/ j.jneb.2007.08.012

5. Keser A. Çıracıoğlu ED. Sağlık ve Beslenme Okuryazarlığı. Yıldırım, F ve Keser, A., Ankara Üniversitesi Yayın 2015;455:39-50.

6. Sjöström L. Review of the key results from the Swedish Obese Subjects (SOS) trial-a prospective controlled intervention study of bariatric surgery. Journal of Internal Medicine. 2013; 273 (3):219-234. doi:10.1111/joim. 12012

7. Buchwald H, Avidor Y, Braunwald E, et al. Bariatric surgery: a systematic review and metaanalysis. JAMA. 2004; 292(14):1724-1737. doi: 10,1001 / jama.292.14.1724

8. Maggard MA, Shugarman LR, Suttorp M, et al. Meta-analysis: surgical treatment of obesity. Annals of Internal Medicine. 2005;142(7):547 -559 .

9. Sjöström L, Narbro K, Sjöström CD, et al. Effects of bariatric surgery on mortality in Swedish obese subjects. New England journal of medicine. 2007;357(8):741-752.

10. Christou NV, Sampalis JS, Liberman M, et al. Surgery decreases long-term mortality, morbidity, and health care use in morbidly obese patients. Annals of Surgery. 2004;240(3) 416-424. doi:10.1097 / 01.sla.0000137343.63376.19

11. Puzziferri N, Roshek TB, Mayo HG, et al. Longterm follow-up after bariatric surgery: a systematic review. JAMA. 2014;312(9):934-942. doi:10.1001/jama.2014.10706

12. Lupoli R, Lembo E, Saldalamacchia G, et al. Bariatric surgery and long-term nutritional issues. World J Diabetes. 2017;8(11):464474.doi: 10.4239 / wjd.v8.i11.464

13. Yüksel A. Bariatrik Cerrahi Operasyonu Geçiren Morbid Obez Bir Hastanın 3 Yil Sonraki Beslenme Durumu: Olgu Sunumu. İzmir Kâtip Çelebi Üniversitesi Sağlık Bilimleri Fakültesi Dergisi. 2016;1(1):39-45

14. Gibbs HD. Nutrition literacy: Foundations and development of an instrument for assessment. University of Illinois at Urbana-Champaign. $\mathrm{PhD}$ Thesis. 2012.

15. Shah H, Shin AC. Meal patterns after bariatric surgery in mice and rats. Appetite. 2019;146 (2020):1-8. doi:10.1016/j.appet.2019.104340
16. Coluzzi I, Raparelli L, Guarnacci L, et al. Food intake and changes in eating behavior after laparoscopic sleeve gastrectomy. Obes Surg. 2016;26 (9):2059-2067. doi: 10.1007/s11695-015-2043-6

17. Laurenius A, Larsson I, Melanson KJ, et al. Decreased energy density and changes in food selection following Roux-en-Y gastric bypass. Eur J Clin Nutr. 2013;67(2):168-173. doi: 10.1038/ ejcn.2012.208

18. Ammon BS, Bellanger DE, Geiselman PJ, Primeaux SD, Yu Y, Greenway FL. Short-term pilot study of the effect of sleeve gastrectomy on food preference. Obes Surg. 2015;25(6):10941097. doi: 10.1007/s11695-015-1602-1

19. Ullrich J, Ernst B, Wilms B, Thurnheer M, Schultes B. Roux-en Y gastric bypass surgery reduces hedonic hunger and improves dietary habits in severely obese subjects. Obes Surg. 2013;23(1):50-55.doi: 10.1007/s11695-0120754-5

20. Bavaresco M, Paganini S, Lima TP, et al. Nutritional course of patients submitted to bariatric surgery. Obes Surg. 2010;20(6):716-721. doi: 10.1007/s1 1695-008-9721-6

21. Kruseman M, Leimgruber A, Zumbach F, Golay A. Dietary, weight, and psychological changes among patients with obesity, 8 years after gastric bypass. J Am Diet Assoc. 2010;110(4):527-534 doi: 10.1016/j.jada.2009.12.028

22. Miller GD, Norris A, Fernandez A. Changes in nutrients and food groups intake following laparoscopic Roux-en-Y gastric bypass (RYGB). Obes Surg. 2014;24(11):1926-1932. doi: 10.1007/s11695-014-1259-1

23. Cesur B, Koçoğlu G. Sümer H. Evaluation İnstrument Of Nutrition Literacy On Adults (EINLA) A Validity And Reliability Study. Integr Food Nutr Metab. 2015;2(3):174-177.

24.Pendergast D, Dewhurst Y. Home Economics and food literacy: An international investigation, International Journal of Home Economics. 2012;5(2):245-263.

25. Özdenk GD, Özcebe LH. Bir üniversite çalışanlarının beslenme okuryazarlığı, beslenme davranışları ve ilişkili faktörler. Türkiye Halk Sağlığı Dergisi. 2018;16(3):178-189. doi:10.20518/tjph.499902

26. Gibbs HD, Kennett AR, Kerling EH, et al. Assessing the nutrition literacy of parents and its relationship with child diet quality. Journal of 
nutrition education and behavior. 2016;48(7):505 -509. doi:10.1016/j.jneb.2016.04.006

27 . Velardo $\mathrm{S}$. The nuances of health literacy, nutrition literacy, and food literacy. Journal of Nutrition Education Behavior. 2015;47(4):385389.doi: 10.1016/j.jneb.2015.04.328

28. Contento RI. Nutrition education linking research, theory and practice, Jones and Bartlett Publishers, Massachusetts 2011.

29. Block L, Childers T, Davis B, Ebert J, Kumanyika L, van Ginkl-Bieshaar M. From nutrients to nurturance: A conceptual introduction to food wellbeing. Journal Public Policy Marketing. 2005;30(1):5-13. doi: 10.1509/jppm.30.1.5

30. Erdem $Z$ ve Kahraman F. Bariatrik hastaların diyetlerinin izlenmesi. İçinde Temel Beslenme ve Diyetetik. Ankara: Güneş Tıp Kitabevi. 1.Bask1;2015. 
Table 1. Demographic characteristics of the participants $(n=60)$.

\begin{tabular}{|c|c|c|c|}
\hline Characteristic & \multicolumn{2}{|c|}{ Case group } & Control group \\
\hline & \multicolumn{2}{|c|}{ Mean $( \pm$ SD) } & Mean $( \pm$ SD) \\
\hline Average age & \multicolumn{2}{|c|}{$36( \pm 7.79)$} & $34.5( \pm 8.35)$ \\
\hline & \multicolumn{2}{|c|}{ n (\%) } & n (\%) \\
\hline $\begin{array}{l}\text { Gender } \\
\text { Female } \\
\text { Male }\end{array}$ & \multicolumn{2}{|c|}{$\begin{array}{l}16(53.3) \\
14(46.7)\end{array}$} & $\begin{array}{l}17(56.7) \\
13(43.3)\end{array}$ \\
\hline $\begin{array}{l}\text { Marital status } \\
\text { Married } \\
\text { Single }\end{array}$ & \multicolumn{2}{|c|}{$\begin{array}{l}20(66.7) \\
10(33.3)\end{array}$} & $\begin{array}{l}18(60) \\
12(40)\end{array}$ \\
\hline $\begin{array}{l}\text { Education level } \\
\text { Primary school } \\
\text { Middle school } \\
\text { High school } \\
\text { University }\end{array}$ & \multicolumn{2}{|c|}{$\begin{array}{c}3(10) \\
3(10) \\
14(46.7) \\
10(33.3)\end{array}$} & $\begin{array}{l}2(6.7) \\
2(6.7) \\
21(70) \\
5(16.7)\end{array}$ \\
\hline $\begin{array}{l}\text { Chronic disease } \\
\text { Yes } \\
\text { No }\end{array}$ & \multicolumn{2}{|c|}{$\begin{array}{c}9(30) \\
21(70)\end{array}$} & $\begin{array}{c}8(26.7) \\
22(73.3)\end{array}$ \\
\hline $\begin{array}{l}\text { If you have chronic disease } \\
\text { Diabetes mellitus } \\
\text { Hypertension }\end{array}$ & \multicolumn{2}{|c|}{$\begin{array}{l}5(16.7) \\
4(13.3)\end{array}$} & $\begin{array}{c}7(23.3) \\
1(3.3)\end{array}$ \\
\hline \multirow[t]{3}{*}{$\begin{array}{l}\text { Type of surgery } \\
\text { Sleeve gastrectomy } \\
\text { roux } n-y \text { gastric bypass }\end{array}$} & \multicolumn{2}{|c|}{$\begin{array}{l}15(50) \\
15(50)\end{array}$} & - \\
\hline & Pre-bariatric & $\begin{array}{l}\text { Post-bariatric } \\
3^{\text {rd }} \text { months }\end{array}$ & Control Group \\
\hline & Mean $( \pm$ SD) & Mean $( \pm$ SD) & Mean ( \pm SD) \\
\hline Average of body mass index $( \pm$ SD) & $44.13 \pm 5.73$ & $33.73 \pm 5.56$ & $21.40 \pm 1.75$ \\
\hline & n (\%) & n (\%) & n (\%) \\
\hline $\begin{array}{l}\text { Nutritional knowledge level } \\
\text { Sufficient } \\
\text { Intermediate } \\
\text { Insufficient }\end{array}$ & $\begin{array}{l}16(53.3) \\
10(33.3) \\
4(13.3)\end{array}$ & $\begin{array}{l}21(70) \\
7(23.3) \\
2(6.7)\end{array}$ & $\begin{array}{c}23(76.7) \\
7(23.3) \\
-\end{array}$ \\
\hline $\begin{array}{l}\text { Nutrition information } \\
\text { I follow the media (TV, Radio, etc.). } \\
\text { I learn internet } \\
\text { I get it from people like friends and } \\
\text { relatives. } \\
\text { I read books about nutrition. }\end{array}$ & $\begin{array}{c}14(46.7) \\
9(30) \\
7(23.3) \\
-\end{array}$ & $\begin{array}{l}7(23.3) \\
18(60) \\
4(6.7) \\
1(3.3)\end{array}$ & $\begin{array}{l}3(10) \\
24(80) \\
2(6.7) \\
1(3.3)\end{array}$ \\
\hline
\end{tabular}


Table 2. Means of Nutrition Literacy Scale in Case and Control Groups $(n=60)$.

\begin{tabular}{|c|l|c|c|c|}
\hline \multicolumn{2}{|c|}{ Nutrition Literacy Scale } & Mean \pm SD (min-max) & TEST & p \\
\hline & Part 1 & $6.33 \pm 2.58(1-9)$ & $\mathbf{1 3 . 4 5 8}$ & $\mathbf{. 0 0 0}$ \\
Pre- & Part 2 & $4.20 \pm 1.37(2-6)$ & $\mathbf{1 6 . 7 3 5}$ & $\mathbf{. 0 0 0}$ \\
bari- & Part 3 & $5.83 \pm 1.68(3-10)$ & $\mathbf{1 8 . 9 8 1}$ & $\mathbf{. 0 0 0}$ \\
atric & Part 4 & $1.60 \pm 0.67(1-3)$ & $\mathbf{1 2 . 9 9 0}$ & $\mathbf{. 0 0 0}$ \\
& Part 5 & $2.13 \pm 1.31(1-5)$ & $\mathbf{8 . 9 4 7}$ & $\mathbf{. 0 0 0}$ \\
& Total Score & $20.10 \pm 5.68(11-30)$ & $\mathbf{1 9 . 3 7 1}$ & $\mathbf{. 0 0 0}$ \\
\hline Post- & Part 1 & $8.67 \pm 0.55(7-9)$ & $\mathbf{8 6 . 3 3 3}$ & $\mathbf{. 0 0 0}$ \\
bari- & Part 2 & $5.57 \pm 0.57(4-6)$ & $\mathbf{5 3 . 6 4 9}$ & $\mathbf{. 0 0 0}$ \\
atric & Part 3 & $8.10 \pm 1.24(5-10)$ & $\mathbf{3 5 . 7 3 5}$ & $\mathbf{. 0 0 0}$ \\
3 rd & Part 4 & $2.80 \pm 0.41(2-3)$ & $\mathbf{3 7 . 6 9 6}$ & $\mathbf{. 0 0 0}$ \\
month & Part 5 & $4.43 \pm 1.55(0-6)$ & $\mathbf{1 5 . 7 0 1}$ & $\mathbf{. 0 0 0}$ \\
S & Total Score & $29.57 \pm 3.07(21-33)$ & $\mathbf{5 2 . 7 4 6}$ & $\mathbf{. 0 0 0}$ \\
\hline & Part 1 & $7.10 \pm 1.94(3-9)$ & $\mathbf{2 0 . 0 8 6}$ & $\mathbf{. 0 0 0}$ \\
Cont- & Part 2 & $4.53 \pm 1.25(2-6)$ & $\mathbf{1 9 . 8 3 0}$ & $\mathbf{. 0 0 0}$ \\
rol & Part 3 & $6.40 \pm 1.85(3-9)$ & $\mathbf{1 8 . 9 5 3}$ & $\mathbf{. 0 0 0}$ \\
Grou & Part 4 & $2.40 \pm 0.72(1-3)$ & $\mathbf{1 8 . 1 5 7}$ & $\mathbf{. 0 0 0}$ \\
p & Part 5 & $3.30 \pm 1.76(0-6)$ & $\mathbf{1 0 . 2 4 3}$ & $\mathbf{. 0 0 0}$ \\
& Total Score & $23.73 \pm 6.18(11-32)$ & $\mathbf{2 1 . 0 3 2}$ & $\mathbf{. 0 0 0}$ \\
\hline
\end{tabular}

Bold indicates significant difference at $p<0.001$. 


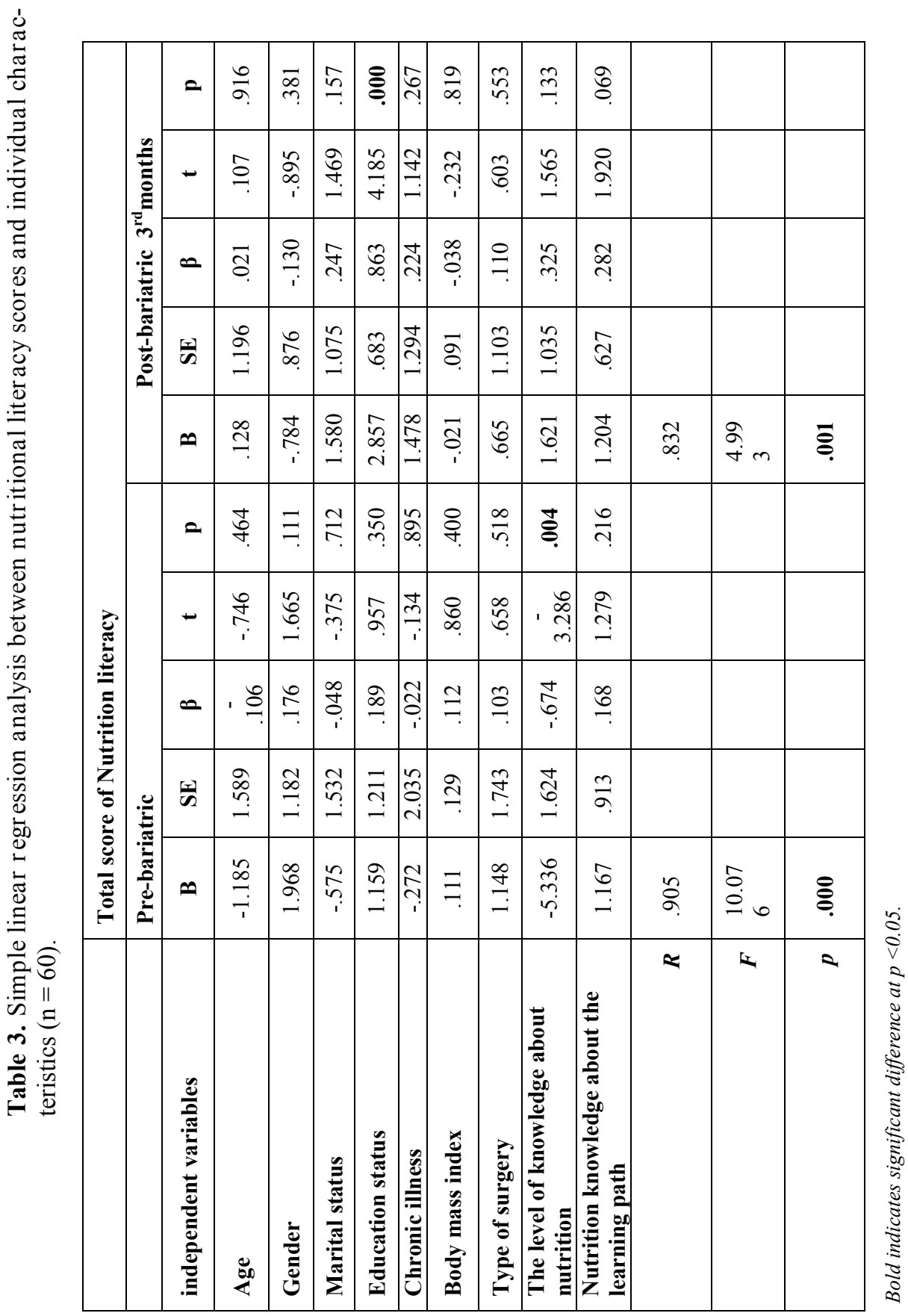




\begin{tabular}{|c|c|}
\hline PART 1 & $\begin{array}{l}0-3 \text { points: insufficient } \\
-4-7 \text { points: borderline } \\
\cdot 8-10 \text { points: enough }\end{array}$ \\
\hline PART 2 & $\begin{array}{l}0-2 \text { points: insufficient } \\
\cdot 3-4 \text { points: borderline } \\
-5-6 \text { points: enough }\end{array}$ \\
\hline PART 3 & $\begin{array}{l}0-3 \text { points: insufficient } \\
\cdot 4-7 \text { points: borderline } \\
\cdot 8-10 \text { points: enough }\end{array}$ \\
\hline PART 4 & $\begin{array}{l}0-1 \text { points: insufficient } \\
\cdot 2 \text { points: borderline } \\
\cdot 3 \text { points: enough } \\
\end{array}$ \\
\hline ART 5 & $\begin{array}{l}\cdot 0-2 \text { points: insufficient } \\
\cdot 3-4 \text { points: borderline } \\
\cdot 5-6 \text { points: enough }\end{array}$ \\
\hline
\end{tabular}

Figure 1. According to section Scale average score of nutritional literacy proficiency levels. 